\title{
Cuyama Valley, California Hydrologic Study: An Assessment of Water Availability
}

\author{
Water resources are under pressure throughout California, particularly in agriculturally dominated valleys. Since \\ 1949, the Cuyama Valley's irrigated acreage has increased from 13 to 35 percent of the valley. Increased agriculture has \\ contributed to the demand for water beyond natural recharge. The tools and information developed for this study can be \\ used to help understand the Cuyama Valley aquifer system, an important resource of Santa Barbara County.
}

To evaluate the historical use and availability for future use of groundwater, the U.S. Geological Survey (USGS), in cooperation with the Santa Barbara County Water Agency, has recently completed a hydrologic study of Cuyama Valley. The study found continued depletion of groundwater storage in the Main zone of the Valley's groundwater basin and, to a lesser extent, in the Sierra Madre Foothills (figs. 1, 2). Since about 1949, nearly 2.1 million acrefeet (acre-ft) of groundwater has been removed from storage in the Cuyama Valley aquifer system, which, on average, is enough to supply every resident of California with water for 4 months.

To complete the study, the USGS developed hydrologic models of Cuyama Valley (Hanson and others, 2014) to analyze water availability. The Cuyama Valley Hydrologic Model (CUVHM) simultaneously accounts for changing water supply and demand across the landscape and simulates surface-water and groundwater flow across the entire valley.

This new hydrologic modeling tool can be used to address issues related to water-resource sustainability that affect food and water security:

- Land-use change and its effects on water resources.

- Effects of water supply and demand on water quality and land subsidence.

- Effects of climate variability and climate change on available water resources.

Currently, groundwater is the sole source for domestic, agricultural, and municipal water use in the Cuyama Valley. Groundwater withdrawals, mainly for irrigation, have resulted in water-level declines of more than 300 feet (ft) in the area since the 1940s.

\section{Cuyama Valley Water Facts}

- There are three groups of subregions in the valley-The Main zone, the Sierra Madre Foothills, and the Ventucopa Uplands (fig. 2). There is minimal groundwater flow between these subregions, which are separated by faults, have different hydrologic and geologic properties, and respond differently to groundwater pumping and recharge. The largest groundwater withdrawals in excess of natural recharge (overdraft) are in the Main zone, with some additional groundwater depletion in the Sierra Madre Foothills, but no permanent depletion in the Ventucopa Uplands.

- Estimated groundwater use for irrigation is twice the 61-year average annual recharge, with about 72 percent of groundwater-storage depletion in the Main-zone subregions.

- Natural recharge and climate have approximately 27-, 22-, 13.5-year cycles that could be used for water-management periods. Groundwater recharge, which occurs primarily in wet years, is not sufficient to replenish the storage depletion driven by current demands.

- Model simulations indicated that a reduction in the amount of water used for irrigation in the Main zone to the amount of average annual recharge would reduce, but not eliminate, groundwater-storage depletion, because most of the recharge is not reaching the aquifers in the Main zone.

- More complete recovery of groundwater storage occurs with cessation of agriculture in the Main zone, but limits valley-wide pumpage to about half of average recharge, which may not allow sustainable agriculture with current practices and land use.

- There are no local criteria for definition of sustainability*, no current water-management practices in place, and no longer term water-management plan for Cuyama Valley.

- Water in the region has historically been of poor quality and continues to be used for ranching, agriculture, and oil and gas production.

- A basin management plan aligned with climate cycles, land use, and planning policies could be developed to reduce groundwater deficits and extend the life of the basin using the CUVHM model.

*Water-resource sustainability is the development and use of water in a manner that can be maintained for an indefinite time without causing unacceptable environmental, economic, or social consequences.

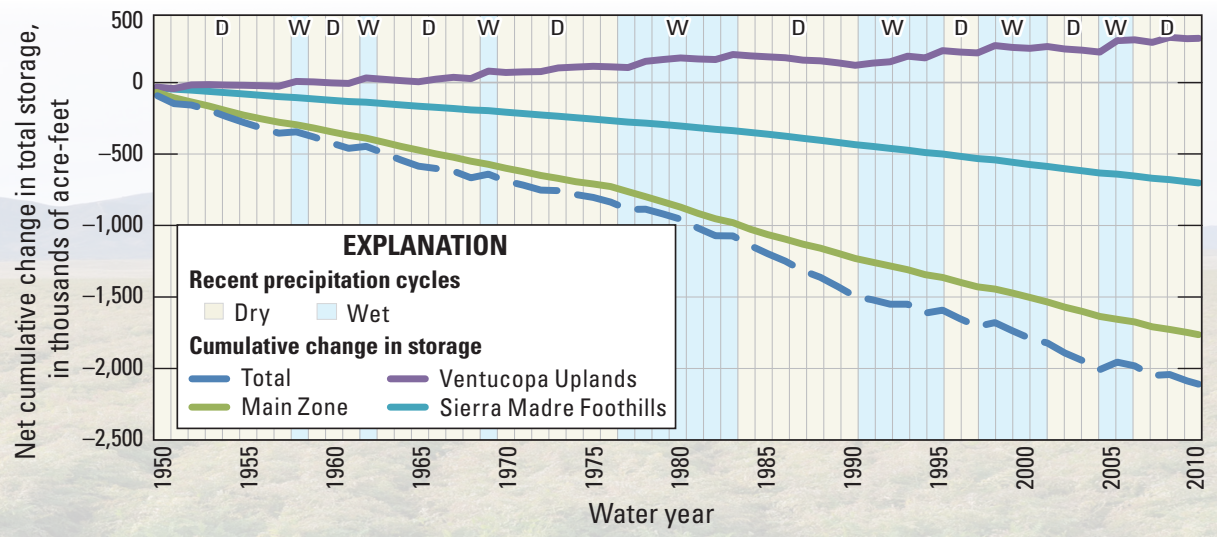

Figure 1. Change in groundwater storage with rapidly declining water levels in a sole-source aquifer were important factors in undertaking and completing this study. To better understand the system, the Cuyama Valley has been split into three groups of subregions: (1) the Main zone, (2) the Sierra Madre Foothills, and (3) the Ventucopa Uplands. Although partially connected hydraulically, the groundwater system in these subregions generally responds independently to different supply sources and demands. 


\section{Cuyama Valley Hydrologic Model}

The CUVHM is built on previous studies conducted by the USGS, Santa Barbara County Water Agency, and other Federal, State, and local studies. The CUVHM was constrained by comparing simulated and historically observed groundwater levels and subsidence. In the Cuyama Valley, the model simulates unmetered historical pumpage and streamflow for changing land use for 61 water years (1950 to 2010). This model provides a better understanding of valley-wide supply and demand for water.

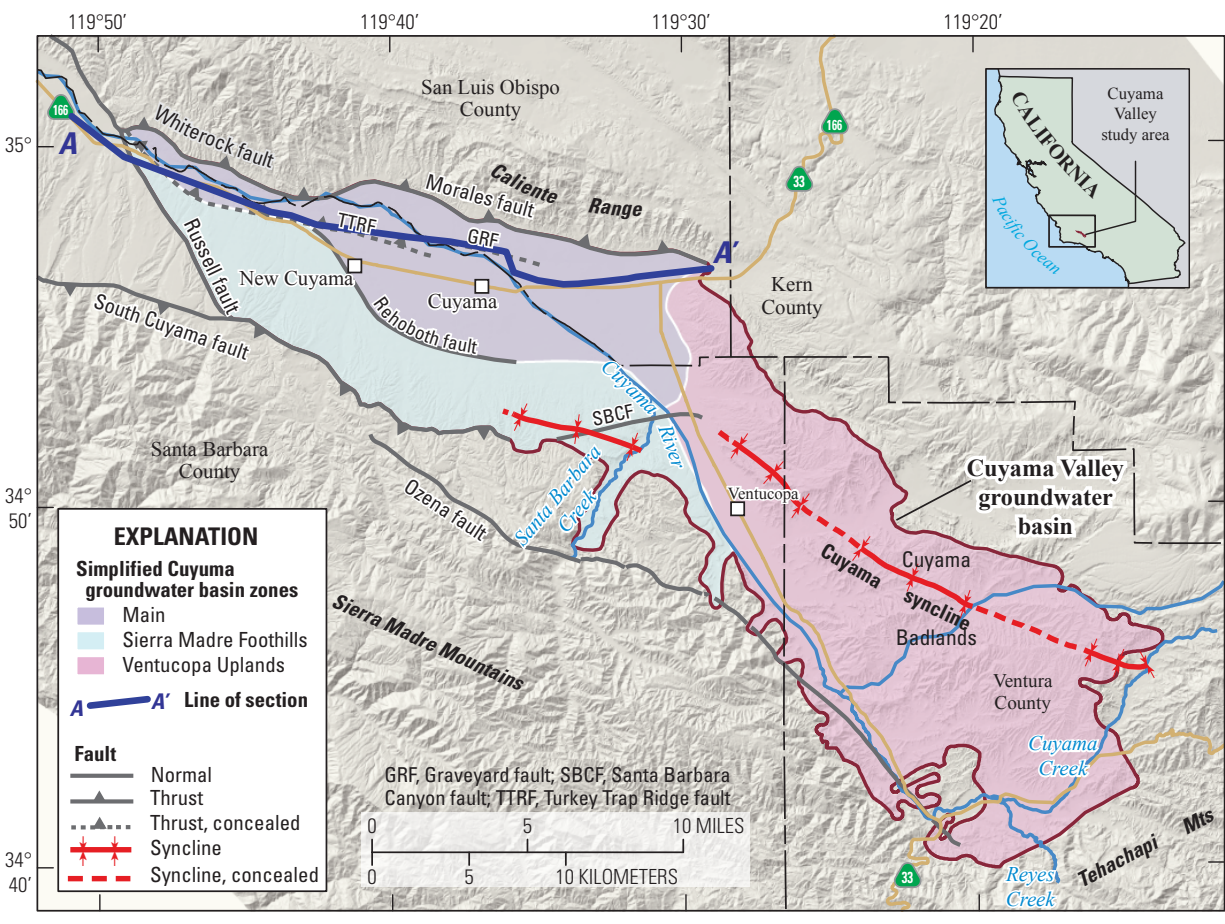

Base modified from U.S. Geological Survey digital data, various scales

Albers Equal Area Projection, North American Datum of 1983

Figure 2. Model framework for the Cuyama Valley Hydrologic Model. To create enough detail to be practical for informing water-management decisions, the aquifer system was divided into 6,817 model cells of 15.4 acres each and, vertically, into 3 model layers as much as $4,710 \mathrm{ft}$ thick. This cell represents the typical land parcel in land-use maps, which will facilitate future linkage of the model to remotely sensed land-use data.

\section{Model Features}

- The combined use and movement of water on the landscape, streams, and aquifers were simulated with an integrated hydrologic model called MODFLOW-OWHM (One Water Hydrologic Model, Hanson and others, 2014).

- The Basin Characteristics Model was used to estimate the recharge and runoff from all of the surrounding watersheds (Hanson and others, 2014).

- A 3-D stratigraphic and texture model was developed to characterize the hydraulic properties and the layering and structure of the aquifers (figs. 3, 4; Sweetkind and others, 2013).

- Data were compiled to simulate changing land ownership, land use, wells, streamflow, and climate.

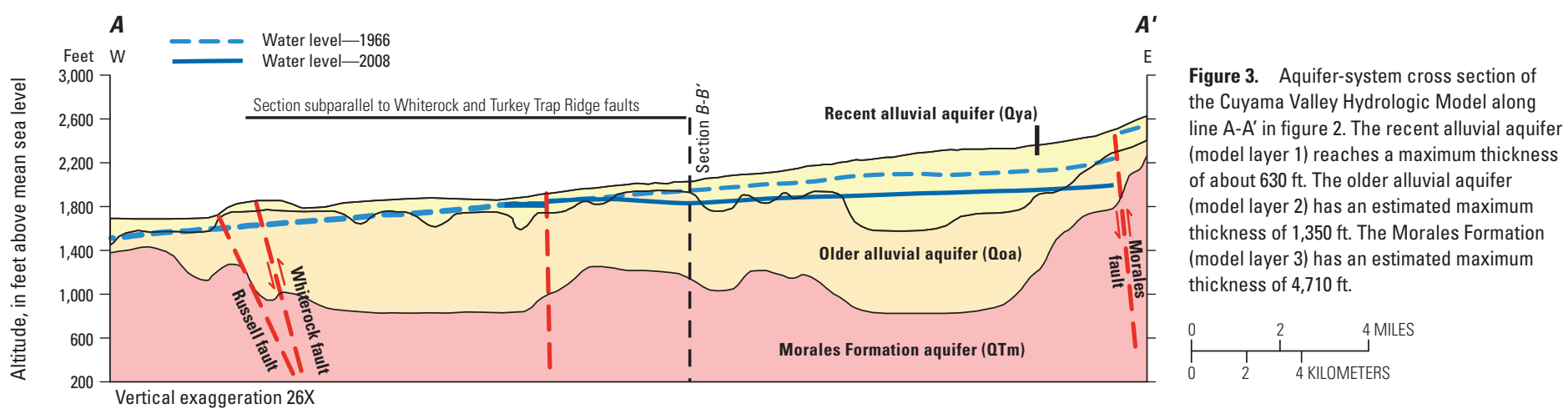

\section{3-D Geologic Framework and Texture Model}

A 3-D geologic framework model was created to define the stratigraphic units and structure of Cuyama Valley (fig. 4). The units and the textural data, such as grain size, sorting, and bedding characteristics, form the basis for estimating the distribution of aquifer hydraulic properties. The framework model was constructed to represent the subsurface geometry of the primary water-bearing units, Recent Alluvium (Qya), Older Alluvium (Qoa), Morales Formation (QTm), and a composite pre-QTm bedrock unit. Interpretation of these data has redefined the structure, extent, thickness, and properties of the aquifer system of the Cuyama Valley.

The Qya has the highest percentage of coarse-grained deposits ( 59 percent) and the greatest spatial correlation with current drainages. The Qoa is overall much finer grained (36 percent coarse) than Qya and generally unrelated to the modern active drainages. QTm is much finer grained (31 percent coarse) than the overlying units and represents deposition of alluvial materials prior to the evolution of the modern topography. 


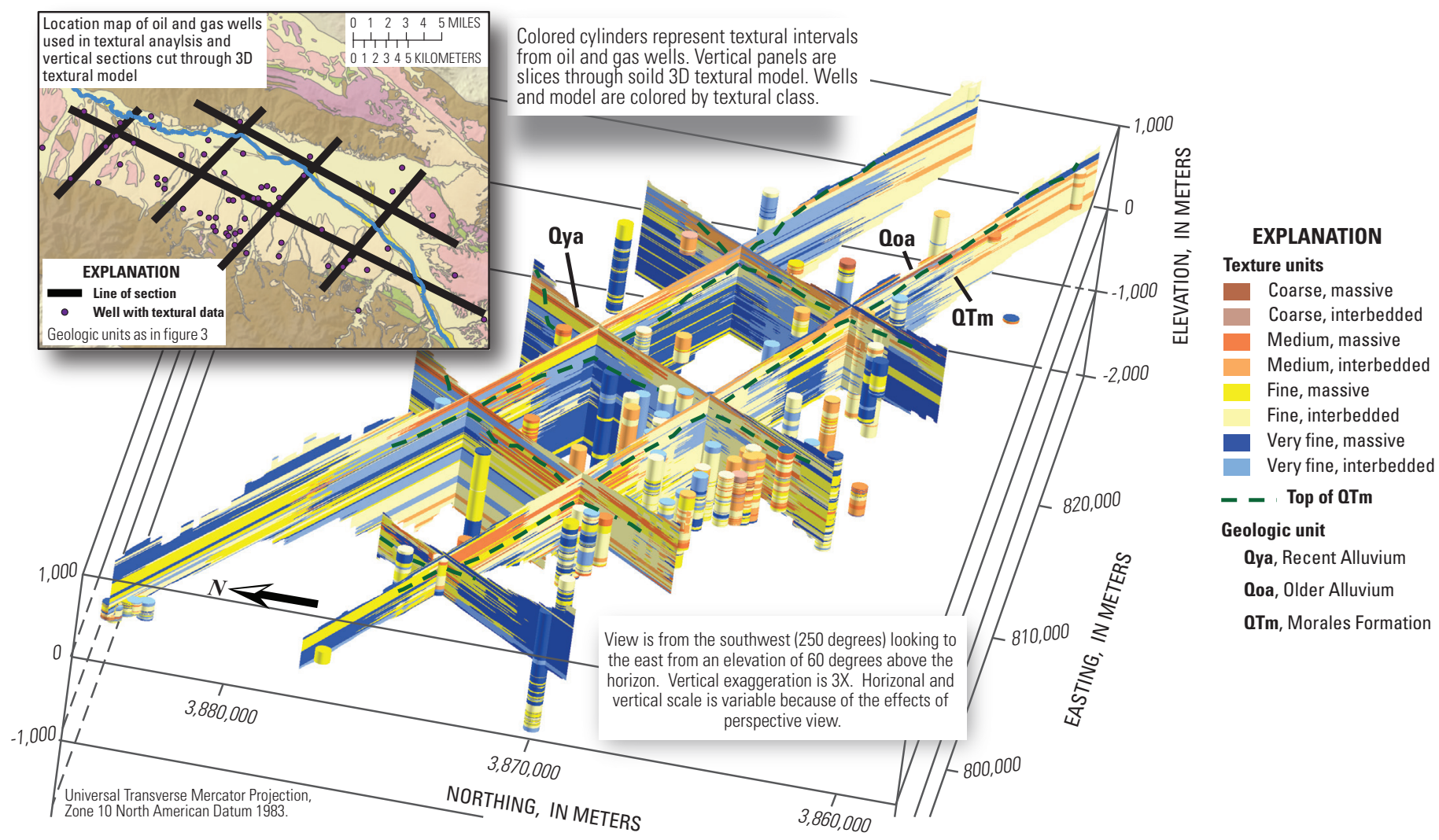

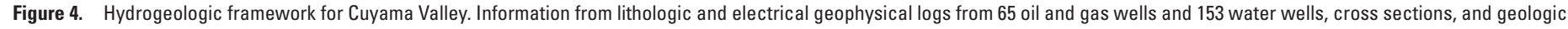
maps were used to create a 3-D model of the geologic framework of the aquifer system.

Faults separate the aquifers into distinct zones in which the response to the use, movement, and consumption of water is similar. Thus, Cuyama Valley can be considered a collection of zones that are partially hydraulically connected, but respond differently to natural and anthropogenic stresses. Data indicated that groundwater does not readily flow vertically between the water-bearing units and that faults restrict the lateral movement of groundwater between different zones.

\section{Temporal and Geospatial Database}

A temporal and geospatial database was developed to capture, compile, manage, store, and analyze the large quantity of data needed to run the CUVHM. Because the integrated hydrologic model of the Cuyama Valley aquifer system simulates temporally varying processes, the database is extremely useful for recognizing and understanding spatial relations within and between data types.

The USGS completed three multiple-well monitoring sites, which provided detailed information that could not be obtained from conventional wells
(Everett and others, 2013). Measurements and observations at these sites provide geophysical data on the alluvial deposits as well as depth-specific data on groundwater levels, hydrologic properties, and water chemistry from selected waterbearing layers within the aquifer system. Measurements at these sites, combined with measurements at existing wells, constitute a new hydrologic monitoring network of the valley. The regional database also includes geomechanical deformation data and data from new upstream streamflow gaging stations on the Cuyama River and Santa Barbara Creek (fig. 2).

\section{Results of Study}

Study results showed that human activities such as irrigated agriculture and associated groundwater pumping have adversely affected the availability of water resources in Cuyama Valley (fig. 5). Measured and simulated groundwater levels indicated substantial waterlevel declines in selected subregions, increased groundwater storage depletion, and seasonal changes in vertical hydraulic head gradients. There is also some additional degradation in already poor water quality, as well as mobilization of natural contaminants and land subsidence in the Main-zone subregions.

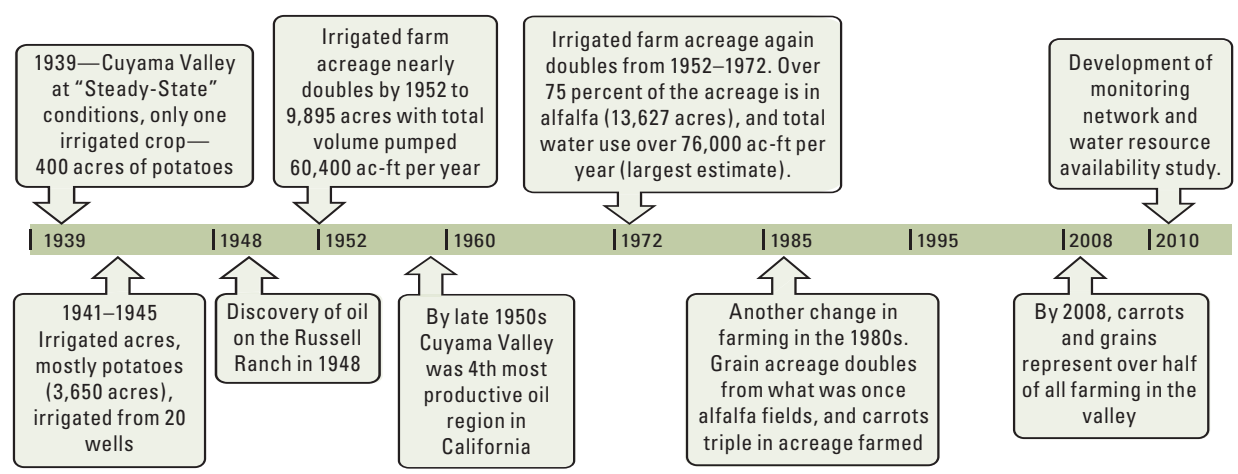

Figure 5. Timeline highlights of Cuyama Valley development. 
Long-term water demand exceeds replenishment, as shown by simulated overdraft of the groundwater basin of about 2.1 million acre- $\mathrm{ft}$ during the 61-year simulation period (1949-2010), with about 72 percent of total groundwater-storage depletion from the Main zone. Groundwater-storage depletion varies considerably from year to year depending on land use, pumpage, and climate conditions. Although interdecadal wet years used to replenish the basin, the predominance of dry and average years with increased water use and sustained storage depletion have diminished the effects of these major recharge events. As a result, large regions have depressed water levels and large unsaturated zones in the Recent and Older alluvium aquifers. These conditions have led to an unsustainable water resource with reduced replenishment, 'overdraft,' poor water quality, and land subsidence.

Hydrographs and simulations of groundwater levels showed annual and seasonal variations, with historical declines of more than $300 \mathrm{ft}$ and rates of decline of 7 feet per year ( $\mathrm{ft} / \mathrm{yr})$ in parts of the south Main zone. Groundwaterlevel declines, averaging 1-2 ft/yr, occur throughout most of the basin. Wells in the Ventucopa Uplands corridor showed cyclical fluctuations in water levels associated with climatic variations and related streamflow events.

Analyses of groundwater samples indicated naturally occurring poorquality water containing elevated levels of total dissolved solids and sulfate throughout the Cuyama Valley. The groundwater generally is very old, indicating limited recharge. Trends indicated that the water quality has been poor historically and showed no indicators of improvement with continued waterlevel declines. Water quality could be slightly deteriorating with the addition of nitrates and other anthropogenic contaminants and the mobilization of natural contaminants such as sulfate, arsenic, and chromium. An exception to this poor quality is in the Ventucopa area, where local recharge has historically created a small area of relatively better quality water.

Data indicated small amounts of permanent subsidence of up to $0.2 \mathrm{ft}$ since 2000 and reduced storage capacity in the aquifer sediments due to groundwater pumping. Simulations of

Table 1. Summary of groundwater-flow budgets for selected regions and periods from the Cuyama Valley Hydrologic Model. [Average-net flows in acre-feet per year]

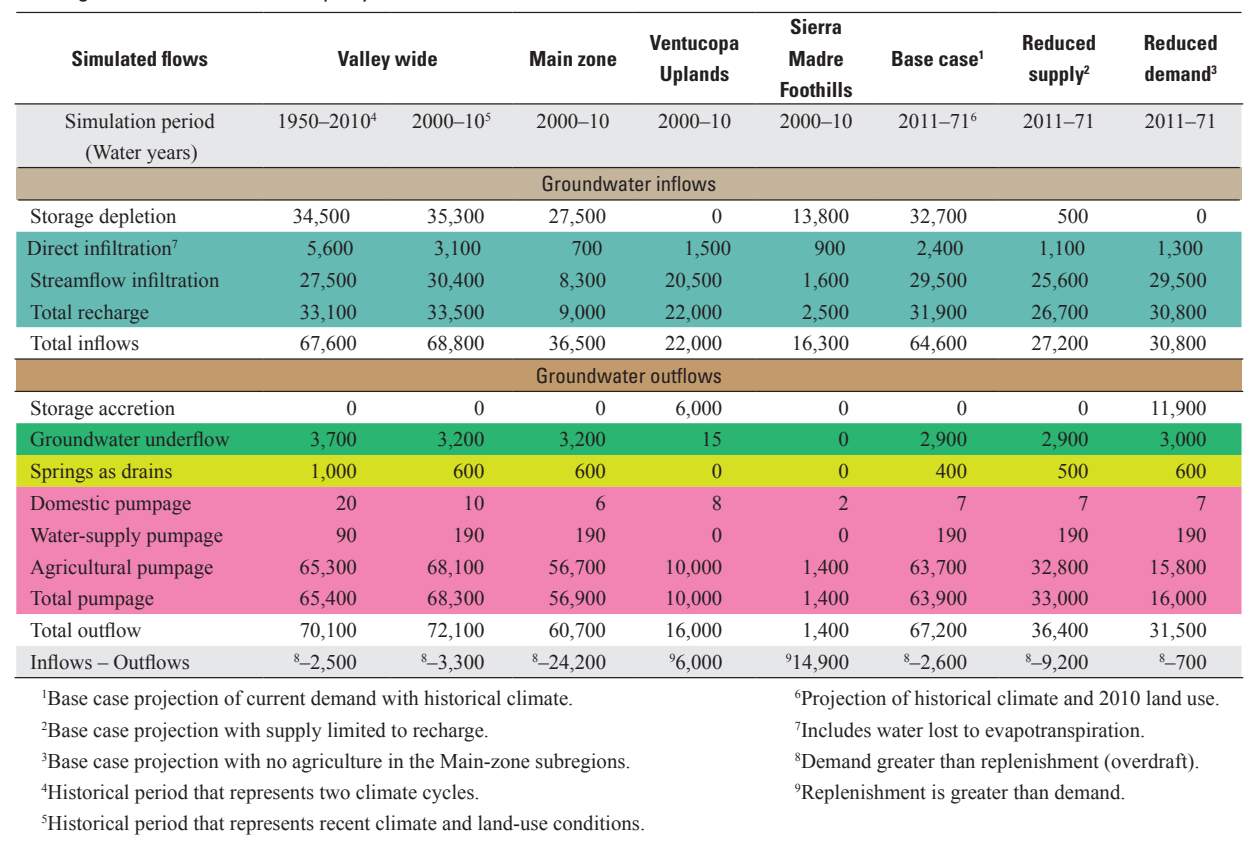

historical conditions indicate near $1.6 \mathrm{ft}$ of subsidence that is spatially centered near New Cuyama and coincident with the groundwater declines in the Main zone. An additional foot of permanent subsidence is projected in the Main zone if current demands continue.

Continued or reduced supply still would result in groundwater depletion (table 1). Recent conditions (2000-10) showed the largest depletion in the Main zone. Reduced demand would allow aquifer recovery, but may not allow adequate irrigation for agriculture.

The bounds of water-resource availability in Cuyama Valley were

\section{For more information contact:}

California Water Science Center

6000 J Street, Placer Hall Sacramento, CA 95819 916-278-3000

\section{Randall T. Hanson}

rthanson@usgs.gov U.S. Geological Survey 4165 Spruance Road, Suite 200 San Diego, CA 92101

\section{Donald Sweetkind}

dsweetkind@usgs.gov U.S Geological Survey, Denver Federal Center, MS 973 Lakewood, CO 80225-0046 assessed, but the criteria for sustainability remain undefined. There is no current management plan, and pumpage is not metered. Projected current demand of water resources (base case) will result in continued groundwater-storage depletion and land subsidence, which probably is not sustainable. Similarly, reducing pumpage to an amount comparable to average recharge (reduced supply) still may not provide a sustainable resource under current agricultural practices and land use. Complete cessation of agriculture in the Main zone (reduced demand) would ensure sustainable water resources but not sustainable agriculture.

\section{References:}

Everett, R.R., Gibbs, D.R., Hanson, R.T., Sweetkind, D.S., Brandt, J.T., Falk, S.E. and Harich, C.R., 2013, Geology, water-quality, hydrology, and geomechanics of the Cuyama Valley groundwater basin, California, 2008-12: U.S. Geological Survey Scientific Investigations Report 2013-5108, 62 p

Hanson, R.T., Boyce, S.E., Schmid, Wolfgang, Hughes, J.D., Mehl, S.M., Leake, S.A., Maddock, Thomas, III, and Niswonger, R.G., 2014, OneWater Hydrologic Flow Model-MODFLOWOWHM: U.S. Geological Survey Techniques and Methods 6-A51, $122 \mathrm{p}$.

Hanson, R.T., Flint, L.E., Faunt, C.C., Gibbs, D., and Schmid, Wolfgang, 2014, Hydrologic models and analysis of water availability in Cuyama Valley, California: U.S. Geological Survey Scientific Investigations Report 2014-5150, 150 p.

Sweetkind, D.S., Faunt, C.C., and Hanson, R.T., 2013, Construction of 3-D geologic framework and textural models for Cuyama Valley groundwater basin, California: U.S. Geological Survey Scientific Investigations Report 2013-5127, 46 p. 